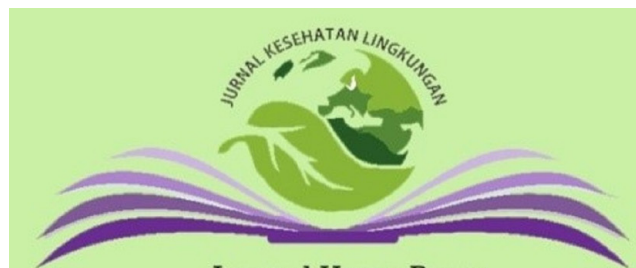

Journal Home Page:

https://e-journal.unair.ac.id/JKL

\section{Jurnal Kesehatan Lingkungan}

Vol. 13 No. 3

DOI: $10.20473 /$ jkl.vl3i3.2021.142-150

ISSN: 1829 - 7285

E-ISSN: 2040 - 881X

\title{
THE NATURAL RADIONUCLIDE ACTIVITY AND THE RISK OF POTENTIAL RADIATION IN HEALTH EFFECT: A STUDY ON BEACH SAND IN MADURA, BALI, AND LOMBOK
}

Yogi Priasetyono ${ }^{1 *}$, Murdahayu Makmur', Heny Suseno ${ }^{1}$, Wahyu Retno Prihatiningsih ${ }^{1}$, Mohamad Nur Yahya ${ }^{1}$, Deddy Irawan Permana Putra ${ }^{1}$

${ }^{1}$ Marine Radioecology Group, Center for Radiation Safety and Metrology Technology, National Nuclear Energy Agency, Jakarta 12710, Indonesia

\section{Corresponding Author:}

*) yogi-priasetyono@batan.go.id

\section{Article Info}

Submitted

6 April 2021

In reviewed

21 May 2021

Accepted

25 June 2021

Available Online

$$
\text { : } 31 \text { July } 2021
$$

Keywords : Natural radionuclides, Beach sand Impact study

Published by Fakultas Kesehatan Masyarakat Universitas Airlangga

\section{Abstract}

Introduction: Beach sand is one of the widely used aggregates in construction, especially in coastal areas. However, beach sand contains a hidden risk, namely radioactive hazards. This research will analyze the radioactive activity of nuclides ${ }^{226} \mathrm{Ra},{ }^{232} \mathrm{Th}$, and ${ }^{40} \mathrm{~K}$ on beach sand and calculate the health risk potential in radiation exposure to the household. Methods: Beach sands sampling was carried out on Madura Island, Bali, and Lombok in 2016. All samples were ovensifted and then put into Marinelli to be chopped using high-purity germanium (HPGe) gamma-ray detectors for three days. Results and Discussion: The average of ${ }^{226} \mathrm{Ra},{ }^{232} \mathrm{Th}$, and ${ }^{40} \mathrm{~K}$ radionuclide activity on the beach sand in Madura were respectively $31.46 \mathrm{~Bq} / \mathrm{kg}, 40.12 \mathrm{~Bq} / \mathrm{kg}$, and $334.04 \mathrm{~Bq}$ / $\mathrm{kg}$; in Bali were $25.10 \mathrm{~Bq} / \mathrm{kg}, 7.71 \mathrm{~Bq} / \mathrm{kg}$, and 165.15. Bq/ $\mathrm{kg}$; and in Lombok the amount is 25.88 $\mathrm{Bq} / \mathrm{kg}, 8.25 \mathrm{~Bq} / \mathrm{kg}$ and $171.99 \mathrm{~Bq} / \mathrm{kg}$. The calculation of the radium equivalent (Raeq) value on beach sand in Madura, Bali, and Lombok has the highest value of $132.72 \mathrm{~Bq} / \mathrm{kg}, 54.06 \mathrm{~Bq} / \mathrm{kg}$, and 55.92 Bq/kg. The gamma index (I) in Madura, Bali, and Lombok was 1.02; 0.39; and 0.40. For the calculation of Hex and Hin in Madura, Bali, and Lombok, the highest were 0.38; 0.15; 0.15; and $0.48 ; 0.23 ; 0.24$. Conclusion: The activity of the three types of natural radionuclides from the three regions is still below the threshold value. Analysis of potential health risks showed in the gamma index value (I) indicator, which exceeds the safe threshold in the Madura beach sand sample. 


\section{INTRODUCTION}

Geological characteristics show that beach sand origin from sand carried by rivers, wind gusts, or weathering of various types of objects (1). Beach sand is often used as an aggregate of raw material in the construction sectors (2). As the need for beach sand as a raw material in construction increases, the demand is even higher, especially by people who live on the coast. They used beach sand for making mortals, which will produce strong mortals with the proper composition (3). Other studies show that the mix of beach sand with shells increases the strength compressive of the mortals (2). Thus, it is predicted that the demand for beach sand will keep increasing from time to time.

However, exposure to the beach sand frequently can give potential hazards to humans such as radioactive (4), which arise naturally from the sand itself, or pollutants carried by sea waters and deposited on the beach or marine sediments. These radioactive elements will emit ionizing radiation in gamma, alpha, and beta rays with high solubility and mobility, which cause significant health problems (5), especially a threat to the building occupants (6).

In general, radionuclides found in the sand are natural and called Naturally Occurring Radioactive Materials (NORMs). Radionuclides such as uranium and thorium are found on the earth occurred naturally (6). The amount of radionuclide concentration will be greatly influenced by geological conditions, mineral composition, and different pollutant sources in each region (7). Many studies suggested that beach sand consists of various radionuclides elements such as ${ }^{226} \mathrm{Ra}$ (Radium), which is a decay of ${ }^{238} \mathrm{U},{ }^{232} \mathrm{Th}$ (Thorium), and ${ }^{40} \mathrm{~K}$ (Potassium). These three radionuclides are the most abundant and have long half-lives in the sand (8).

The amount of sand used in building construction will determine the level of radiation exposure to the occupants within a certain period (9). According to the previous study, information regarding the potential radioactive hazards in beach sand can be recommended to stakeholders in many countries to adopt regulations not to use it as building materials.

Several studies have been conducted to determine the magnitude concentration of the radionuclides in beach sand, such as in Thailand (10), in the Canary Islands (11), in India (12), and Las Canteras, Spain (13). The total radiation dose has received by humans does not only come from natural radionuclides such as the combination of ${ }^{40} \mathrm{~K},{ }^{232} \mathrm{Th}$, and ${ }^{226} \mathrm{Ra}$. However, there is also cosmic radiation, such as photons and muons. There has been a safe recommendation set to threshold limit the dose of radiation exposure to humans. Meanwhile, Brazil, India, and China are considered countries with the highest radiation exposures (14).

Several other studies have also been conducted to examine the activity of natural radionuclides and their potential hazards in building materials such as ceramics (6,15-16), gravel (15), sand (15), cement (15-18), and bricks $(15,18)$. Moreover, these studies also examined both internal and external hazards that these radionuclides can potentially give to the building occupants.

Internal and external radiations refer to ionizing radionuclides expose to the building occupants from inside or outside the body. Internal radiations such as radium and thorium have become health problems, especially for the building occupants. Radionuclides such as radium are very dangerous as they can settle in human bones. A similar risk also is posed by thorium which entered the lungs and bones as dust or other materials of the building occupants (19-20). The potential hazards of external radiation such as gamma rays likely depend on the amount of time the building occupants spend in the room (8).

Several studies have been conducted in Indonesia to examine the natural radionuclides caught in the marine compartment and their potential risk to humans' health (21). However, there is still no study that specifically addresses the amount of radioactivity levels in building materials. Therefore, a more in-depth study of the potential of radiological hazards caught in the sand is needed when used as a building material. This study is expected to be useful, especially for every occupant of the building.

This study discussed the amount of natural radionuclide activity found in beach sand from Madura, Bali, and Lombok. In addition to that, it also addressed the potential radiological risks to humans health, which can be helpful references for relevant decision-makers.

\section{METHODS}

\section{Analysis of ${ }^{226} \mathrm{Ra},{ }^{232} \mathrm{Th}$ and ${ }^{40} \mathrm{~K}$ Radionuclides}

The sampling was carried out at several points on the coasts of Madura, Bali, and Lombok islands in 2016. These three islands located adjacent to the island of Java, where Madura is in the Northeast of Java while Bali and Lombok were close to each other. The sample was taken randomly and spread using a grab sampler. There were 11 points selected as samples where each point was taken approximately $1.5 \mathrm{~kg}$ of beach sand. 
The sand samples were tightly wrapped in plastic clips, labelled, and taken to the laboratory for preparation. The sample would be dried using an oven (Memmert, Germany) at $80^{\circ} \mathrm{C}$ for several days to remove the moisture. After that, the samples were crushed and sieved, then stored in Marinelli as much as $1 \mathrm{~kg}$ and tightly closed for 28 days to ensure the equilibrium between the ${ }^{226} \mathrm{Ra}$ and ${ }^{232} \mathrm{Th}$ nuclides. Samples stored then measured using a Gama High Purity Germanium (HPGe) detector with a relative efficiency of $20-25 \%$ for three days to detect gamma radiation emitted from the samples. During the measurement process, the samples were contained with lead to minimize the natural radiation interference around the laboratory. The detector machine was routinely and periodically calibrated based on CRM (Certified Reference Material) Europium (152Eu) to ensure the measurement runs accurately. Moreover, the detector's background radiation value was also set before the measurement process.

The samples had been measured for three days, calculated using the Genie 2000 Gamma Acquisition \& Analysis application to enumerate gamma spectrum energy would produce in the form of energy peaks that represent the radioactive substances contained in the samples. The activity of ${ }^{226} \mathrm{Ra}$ could be identified at low energy of $186.2 \mathrm{keV}$. Moreover, the activity of ${ }^{226} \mathrm{Ra}$ could also be calculated through its decays, ${ }^{214} \mathrm{~Pb}$ and ${ }^{214} \mathrm{Bi}$, at energies of 295.2, $351.9 \mathrm{keV}\left({ }^{214} \mathrm{~Pb}\right)$ and $609.3,768.3$, $934.1,1120.3,1238.1,1764.5 \mathrm{keV}\left({ }^{214} \mathrm{Bi}\right)$, after 28 days when they reached the equilibrium. Further, the activity of ${ }^{232} \mathrm{Th}$ could also be calculated through its decays, ${ }^{228} \mathrm{Ac}$ and ${ }^{212} \mathrm{~Pb}$, at energies of 209.2, 328.0, 409.5, 463.0, 794.9, 835.7, 911.2, 964.7, 968.9 and $300.1 \mathrm{keV}$. The characteristics of ${ }^{226} \mathrm{Ra}$ and ${ }^{232} \mathrm{Th}$ are different from ${ }^{40} \mathrm{~K}$ which could be seen directly without the help from its decays due to its abundance in nature. The activity of ${ }^{40} \mathrm{~K}$ could be seen at an energy of $1460.8 \mathrm{keV}(10,22)$.

\section{Literature on Radiation Dose}

To understand how big the hazards, there were several assessed indicators such as the activity value of radium equivalent $\left(\mathrm{Ra}_{\mathrm{eq}}\right)$, gamma activity concentration index $(\mathrm{I})$, as well as external $\left(\mathrm{H}_{\mathrm{ex}}\right)$, and internal $\left(\mathrm{H}_{\text {in }}\right)$ hazard indexes.

$\mathrm{Ra}_{\mathrm{eq}}$ was used as a marker for both evaluation and prediction of radiation exposure based on radiation dose. It was different from hazard criterion I, which is the most commonly used indicator, especially for building materials. The results of $\mathrm{Ra}_{\mathrm{eq}}$ analysis were used to regulate the building materials. All building materials must not produce an effective annual dose of more than $1 \mathrm{mSv}$ to the building occupants.

Meanwhile, the $\mathrm{H}_{\mathrm{ex}}$ was used to see the level of external exposure received by the building occupants in a certain period. This was different from the $\mathrm{H}_{\text {in }}$ which is used to see the level of internal exposure received by humans due to radionuclides that enter through breathing or food $(12,23)$. The following formulas were used to calculate $\mathrm{Ra}_{\mathrm{eq}}, \mathrm{I}, \mathrm{H}_{\mathrm{ex}}$, and $\mathrm{H}_{\mathrm{in}}$ in this study: (2425)

$$
\begin{aligned}
& \mathrm{Ra}_{\text {eq }}=\mathrm{A}_{\mathrm{Ra}}+1.43 \mathrm{~A}_{\mathrm{Th}}+0.077 \mathrm{~A}_{\mathrm{K}} \\
& \mathrm{I}=\mathrm{A}_{\mathrm{Ra}} / 150+\mathrm{A}_{\mathrm{Th}} / 100+\mathrm{A}_{\mathrm{K}} / 1500 \\
& \mathrm{H}_{\text {ex }}=\mathrm{A}_{\mathrm{Ra}} / 370+\mathrm{A}_{\mathrm{Th}} / 259+\mathrm{A}_{\mathrm{K}} / 4810 \\
& \mathrm{H}_{\text {in }}=\mathrm{A}_{\mathrm{Ra}} / 185+\mathrm{A}_{\mathrm{Th}} / 259+\mathrm{A}_{\mathrm{K}} / 4810
\end{aligned}
$$

With these formulas, this study could calculate the amount of radiation found in a building and evaluated the radiological hazards potentially received by individuals occupying a building $(12,18)$.

\section{RESULTS}

\section{The Activity of ${ }^{226} \mathrm{Ra},{ }^{232} \mathrm{Th}$ and ${ }^{40} \mathrm{~K}$ Radionuclides}

The results of the radionucleid activity as shown in Table 1 . The activity of ${ }^{226} \mathrm{Ra},{ }^{232} \mathrm{Th}$, and ${ }^{40} \mathrm{~K}$ found in the coast of Madura ranged from $27.28 \mathrm{~Bq} / \mathrm{kg}$ to $37.86 \mathrm{~Bq} / \mathrm{kg}$, $36.47 \mathrm{~Bq} / \mathrm{kg}$ to $46.9 \mathrm{~Bq} / \mathrm{kg}$, and $257.20 \mathrm{~Bq} / \mathrm{kg}$ to 451.99 $\mathrm{Bq} / \mathrm{kg}$ with an average of $31.46,40.12$ and $334.04 \mathrm{~Bq} /$ $\mathrm{kg}$ for each radionuclide. In addition, the activity of these radionuclides found on the coast of Bali ranged from $21.06 \mathrm{~Bq} / \mathrm{kg}$ to $31.13 \mathrm{~Bq} / \mathrm{kg}, 6.155 \mathrm{~Bq} / \mathrm{kg}$ to $8.785 \mathrm{~Bq} /$ $\mathrm{kg}$, and $145.89 \mathrm{~Bq} / \mathrm{kg}$ to $183.45 \mathrm{~Bq} / \mathrm{kg}$ with an average of $25.10,7.71$ and $165.15 \mathrm{~B} / \mathrm{kg}$ for each radionuclide. Meanwhile, for the Lombok's coast, the activity ranged from $18.18 \mathrm{~Bq} / \mathrm{kg}$ to $32.52 \mathrm{~Bq} / \mathrm{kg}, 6.38 \mathrm{~Bq} / \mathrm{kg}$ to $10.02 \mathrm{~Bq} /$ $\mathrm{kg}$, and $150.31 \mathrm{~Bq} / \mathrm{kg}$ to $189.94 \mathrm{~Bq} / \mathrm{kg}$ with an average of $25.88,8.25$, and $171.99 \mathrm{~Bq} / \mathrm{kg}$.

\section{The Evaluation of Hazardous Radiological Effects}

This result of estimated the potential radiological hazards of $\mathrm{Ra}_{\mathrm{eq}}, \mathrm{I}, \mathrm{H}_{\mathrm{ex}}$, and $\mathrm{H}_{\text {in }}$ as shown in Table 4. The highest value of $\mathrm{Ra}_{\mathrm{eq}}$ was found in Madura beach sand with ranged from $101.19 \mathrm{~Bq} / \mathrm{kg}$ to $132.72 \mathrm{~Bq} / \mathrm{kg}$. Meanwhile, Bali have the smaller $\mathrm{Ra}_{\mathrm{eq}}$ than Madura. Lombok has the smallest $\mathrm{Ra}_{\mathrm{eq}}$ with ranged from 41.33 $\mathrm{Bq} / \mathrm{kg}$ to $55.92 \mathrm{~Bq} / \mathrm{kg}$. As for parameter I, Madura ranged from 0.73 to 1.02 while Bali and Lombok ranged from 46.07 to 54.06 and 41.33 to 55.92 . As for parameter $\mathrm{H}_{\mathrm{ex}}$, Madura, Bali, and Lombok ranged from 0.27 to 0.38 , 
0.12 to 0.15 , and 0.11 to 0.15 respectively. As for last parameter $\mathrm{H}_{\text {in }}$, Madura, Bali and Lombok ranged from 0.35 to $0.48,0.18$ to 0.23 and 0.16 to 0.24 respectively.

Table 1. Natural Radionuclide Activity in Madura, Bali, and Lombok

\begin{tabular}{|c|c|c|c|c|}
\hline \multirow{2}{*}{ Sample } & \multirow{2}{*}{ Location } & \multicolumn{3}{|c|}{ Radionuclide (Bq/kg) } \\
\hline & & ${ }^{226} \mathbf{R a}$ & ${ }^{232} \mathrm{Th}$ & ${ }^{40} \mathbf{K}$ \\
\hline Madura 1 & $\begin{array}{l}112^{0} 40^{\prime} 22.8^{\prime \prime} \mathrm{E} \\
7^{0} 22^{\prime} 38.4^{\prime \prime} \mathrm{S}\end{array}$ & $37.86 \pm 4.47$ & $46.9 \pm 6.2$ & $451.99 \pm 79.41$ \\
\hline Madura 2 & $\begin{array}{l}113^{0} 6^{\prime} 39.6 ” \mathrm{E} \\
6^{0} 52^{\prime} 12^{\prime \prime} \mathrm{S}\end{array}$ & $29.24 \pm 3.44$ & $36.47 \pm 4.84$ & $257.20 \pm 45.19$ \\
\hline Madura 3 & $\begin{array}{l}113^{0} 25^{\prime} 48^{\prime \prime} \mathrm{E} \\
7^{0} 13^{\prime} 15.6 ” \mathrm{~S}\end{array}$ & $27.28 \pm 3.21$ & $36.98 \pm 5.8$ & $292.94 \pm 51.46$ \\
\hline Bali 1 & $\begin{array}{l}115^{0} 18^{\prime} 35.11^{\prime \prime} \mathrm{E} \\
8^{0} 52^{\prime} 39.69^{\prime \prime} \mathrm{S}\end{array}$ & $23.13 \pm 3.87$ & $8.185 \pm 0.45$ & $145.89 \pm 16.98$ \\
\hline Bali 2 & $\begin{array}{l}114^{0} 58^{\prime} 9,03 \text { ', E } \\
8036 \text { '22.4”S }\end{array}$ & $21.06 \pm 2.31$ & $8.785 \pm 0.94$ & $166.13 \pm 17.32$ \\
\hline Bali 3 & $\begin{array}{l}114^{0} 45^{\prime} 57.35^{\prime \prime} \mathrm{E} \\
8^{0} 28^{\prime} 3.73 ” \mathrm{~S}\end{array}$ & $31.13 \pm 4.01$ & $6.155 \pm 0.36$ & $183.45 \pm 19.42$ \\
\hline Lombok 1 & $\begin{array}{l}115^{0} 57^{\prime} 48.38^{\prime \prime} \mathrm{E} \\
8^{0} 27^{\prime} 24.60^{\prime \prime S}\end{array}$ & $30.88 \pm 1.35$ & $6.38 \pm 0.34$ & $189.94 \pm 3.28$ \\
\hline Lombok 2 & $\begin{array}{l}115^{0} 58^{\prime} 47.7^{\prime \prime} \mathrm{E} \\
8^{0} 40^{\prime} 7.25^{\prime} \mathrm{S}\end{array}$ & $32.52 \pm 4.12$ & $8.27 \pm 0.42$ & $150.31 \pm 10.13$ \\
\hline Lombok 3 & $\begin{array}{l}116^{0} 8^{\prime} 40.97 ’ \mathrm{E} \\
8^{0} 59^{\prime} 59.24 ’ \mathrm{~S}\end{array}$ & $\begin{array}{c}25.32 \pm \\
31.51\end{array}$ & $10.02 \pm 0.51$ & $182.32 \pm 11.81$ \\
\hline Lombok 4 & $\begin{array}{l}116^{0} 35^{\prime} 52.44 \text { ”E } \\
8^{0} 47^{\prime} 7.5 \text { 'S }\end{array}$ & $18.18 \pm 2.49$ & $7.24 \pm 0.35$ & $166.29 \pm 14.07$ \\
\hline Lombok 5 & $\begin{array}{l}116^{0} 16^{\prime} 45.46^{\prime \prime} \mathrm{E} \\
8^{0} 11^{\prime} 55^{\prime \prime} \mathrm{S}\end{array}$ & $22.52 \pm 2.98$ & $9.32 \pm 0.55$ & $171.12 \pm 15.34$ \\
\hline
\end{tabular}

Table 2. Comparison of Activity Concentrations (Bq/ kg) at ${ }^{226} \mathrm{Ra},{ }^{232} \mathrm{Th}$, and ${ }^{40} \mathrm{~K}$ in the Coastal Environment in Indonesia

\begin{tabular}{|c|c|c|c|c|c|c|c|}
\hline \multirow{2}{*}{ Location } & \multicolumn{2}{|c|}{${ }^{226} \mathbf{R a}$} & \multicolumn{2}{|c|}{${ }^{232} \mathrm{Th}$} & \multicolumn{2}{|c|}{${ }^{40} \mathrm{~K}$} & \multirow{2}{*}{ References } \\
\hline & Range & Mean & Range & Mean & Range & Mean & \\
\hline Madura & $\begin{array}{c}27.28- \\
37.86\end{array}$ & 31.46 & $\begin{array}{c}36.47- \\
46.9\end{array}$ & 40.12 & $\begin{array}{c}257.20- \\
451.99\end{array}$ & 334.04 & This work \\
\hline Bali & $\begin{array}{l}21.06- \\
31.13\end{array}$ & 25.10 & $\begin{array}{l}6.155- \\
8.785\end{array}$ & 7.71 & $\begin{array}{c}145.89- \\
183.45\end{array}$ & 165.15 & This work \\
\hline Lombok & $\begin{array}{l}18.18- \\
32.52\end{array}$ & 25.88 & $\begin{array}{l}6.38- \\
10.02\end{array}$ & 8.25 & $\begin{array}{c}150.31- \\
189.94\end{array}$ & 171.99 & This work \\
\hline Bengkalis & $\begin{array}{l}25.01- \\
109.62\end{array}$ & 56.45 & $\begin{array}{c}16.03- \\
49.80\end{array}$ & 30.67 & $\begin{array}{l}99.39- \\
255.93\end{array}$ & 185.49 & (35) \\
\hline Jakarta & $\begin{array}{l}42.0- \\
64.92\end{array}$ & 51.44 & - & - & - & - & (20) \\
\hline Sluke & $\begin{array}{l}66.07- \\
95.24\end{array}$ & 76.70 & - & - & $\begin{array}{c}160.54- \\
503.87\end{array}$ & 365.79 & (21) \\
\hline Kalimantan & $\begin{array}{l}1.09- \\
53.46\end{array}$ & - & $\begin{array}{l}1.25- \\
32.91\end{array}$ & - & $\begin{array}{l}28.58- \\
596.83\end{array}$ & - & (36) \\
\hline
\end{tabular}

Table 3. Comparison of Activity Concentrations (Bq/ kg) at ${ }^{226} \mathrm{Ra},{ }^{232} \mathrm{Th}$, and ${ }^{40} \mathrm{~K}$ on Beach Sand from Several Countries

\begin{tabular}{|c|c|c|c|c|c|c|c|}
\hline \multirow{2}{*}{ Location } & \multicolumn{2}{|c|}{${ }^{226} \mathbf{R a}$} & \multicolumn{2}{|c|}{${ }^{232} \mathrm{Th}$} & \multicolumn{2}{|c|}{${ }^{40} \mathrm{~K}$} & \multirow{2}{*}{ References } \\
\hline & Range & Mean & Range & Mean & Range & Mean & \\
\hline Madura, & $18.18-$ & 27.48 & $6.16-$ & 18.69 & 145.89- & 223.73 & This work \\
\hline Bali and & 37.86 & & 46.9 & & 451.99 & & \\
\hline Lombok & & & & & & & \\
\hline Thailand & $1.6-83.1$ & 22.6 & $\begin{array}{l}0.3- \\
73.9\end{array}$ & 26.4 & $\begin{array}{c}1.9- \\
1376\end{array}$ & 523.0 & (10) \\
\hline $\begin{array}{l}\text { Bangladesh } \\
\text { (Whitesand) }\end{array}$ & $\begin{array}{c}33.3- \\
63.3\end{array}$ & 49.4 & $\begin{array}{l}60.8- \\
82.5\end{array}$ & 71.6 & $\begin{array}{l}832.4- \\
1046.1\end{array}$ & 927.2 & (18) \\
\hline $\begin{array}{l}\text { Bangladesh } \\
\text { (Redsand) }\end{array}$ & $\begin{array}{c}46.0- \\
67.4\end{array}$ & 59.2 & $\begin{array}{l}65.6- \\
94.6\end{array}$ & 82.0 & $\begin{array}{l}889.3- \\
1136.2\end{array}$ & 1035.6 & (18) \\
\hline $\begin{array}{l}\text { Gran } \\
\text { Canaria, } \\
\text { Spain (S) }\end{array}$ & $\begin{array}{l}8.1- \\
26.7\end{array}$ & 17.1 & $\begin{array}{l}7.4- \\
41.9\end{array}$ & 20.4 & $\begin{array}{l}130- \\
1055\end{array}$ & 460.21 & (11) \\
\hline $\begin{array}{l}\text { Gran } \\
\text { Canaria, } \\
\text { Spain (D) }\end{array}$ & $6.5-29.7$ & 18.2 & $\begin{array}{l}6.5- \\
40.6\end{array}$ & 22.3 & $83-972$ & 501 & (11) \\
\hline $\begin{array}{l}\text { Tamilnadu } \\
\text { State, India }\end{array}$ & - & - & $\begin{array}{c}\text { BDL- } \\
2938.31\end{array}$ & 26.32 & $\begin{array}{c}\text { BDL- } \\
570.04\end{array}$ & 202.87 & (12) \\
\hline $\begin{array}{l}\text { Guangxi } \\
\text { Province, } \\
\text { China } \\
\end{array}$ & $\begin{array}{l}4.88- \\
9.43\end{array}$ & 7.07 & - & - & $\begin{array}{c}2.76- \\
109.16\end{array}$ & 28.94 & (33) \\
\hline $\begin{array}{l}\text { Southern } \\
\text { India }\end{array}$ & $\begin{array}{l}1.56- \\
32.38\end{array}$ & - & $\begin{array}{l}34.77- \\
229.30\end{array}$ & - & $\begin{array}{l}5.21- \\
88.39 \\
\end{array}$ & - & (34) \\
\hline $\begin{array}{l}\text { Langkawi } \\
\text { Island, } \\
\text { Malaysia } \\
\text { (Black } \\
\text { Sand) }\end{array}$ & $\begin{array}{l}451.4- \\
2411.4\end{array}$ & 1478.1 & $\begin{array}{l}232.2- \\
1271.9\end{array}$ & 718.3 & $\begin{array}{l}60.9- \\
135.6\end{array}$ & 102.7 & (22) \\
\hline $\begin{array}{l}\text { Langkawi } \\
\text { Island, } \\
\text { Malaysia } \\
\text { (White } \\
\text { Sand) }\end{array}$ & $8.3-13.7$ & 9.8 & $4.5-9.4$ & 5.9 & $\begin{array}{l}84.6- \\
132.5\end{array}$ & 101.7 & (22) \\
\hline Turkey & BDL-65 & - & $\begin{array}{c}\text { BDL- } \\
28\end{array}$ & - & $9-1936$ & - & (37) \\
\hline Temsah & & & & & & & \\
\hline $\begin{array}{l}\text { Lake } \\
\text { Beach, } \\
\text { Egypt }\end{array}$ & $\begin{array}{l}4.29- \\
30.06\end{array}$ & 9.57 & $\begin{array}{l}6.96- \\
39.24\end{array}$ & 13.77 & $\begin{array}{l}37.17- \\
242.25\end{array}$ & 141.64 & (14) \\
\hline
\end{tabular}

Table 4. Calculation of Radiological Hazard Index Values in Beach Sands of Madura, Bali, and Lombok, Indonesia

\begin{tabular}{lcccc}
\hline \multicolumn{1}{c}{ Location } & $\mathbf{R a}(\mathbf{B q} / \mathbf{k g})$ & $\mathbf{I}$ & $\mathbf{H}_{\mathbf{e x}}$ & $\mathbf{H}_{\text {in }}$ \\
\hline Madura 1 & 139.72 & 1.02 & 0.38 & 0.48 \\
Madura 2 & 101.19 & 0.73 & 0.27 & 0.35 \\
Madura 3 & 102.71 & 0.75 & 0.28 & 0.35 \\
Bali 1 & 46.07 & 0.33 & 0.12 & 0.19 \\
Bali 2 & 46.41 & 0.34 & 0.13 & 0.18 \\
Bali 3 & 54.06 & 0.39 & 0.15 & 0.23 \\
Lombok 1 & 54.64 & 0.40 & 0.15 & 0.23 \\
Lombok 2 & 55.92 & 0.40 & 0.15 & 0.24 \\
Lombok 3 & 53.69 & 0.39 & 0.15 & 0.21 \\
Lombok 4 & 41.33 & 0.30 & 0.11 & 0.16 \\
Lombok 5 & 49.02 & 0.36 & 0.13 & 0.19 \\
\hline Recommended & $<370$ & $<0.5$ & $<1$ & $<1$ \\
Values & & & & \\
\hline
\end{tabular}




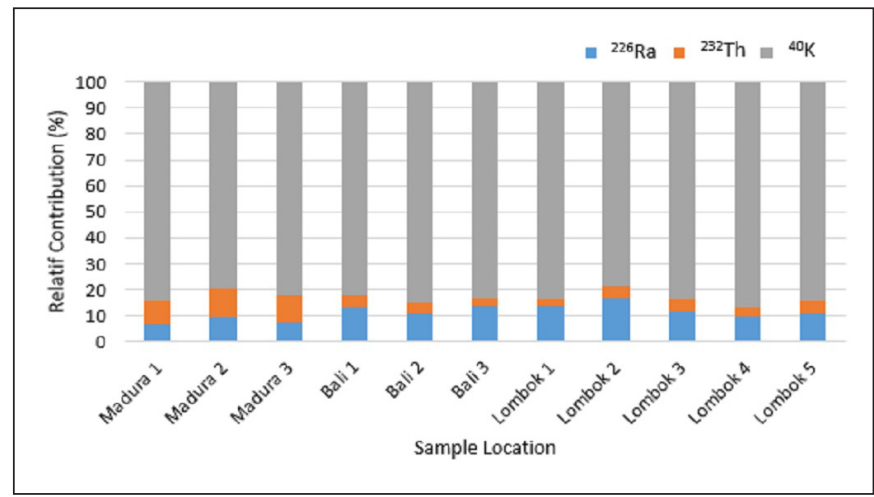

Figure 1. Relative Concentrations of ${ }^{226} \mathrm{Ra},{ }^{232} \mathrm{Th}$ and ${ }^{40} \mathrm{~K}$ to Total Activity

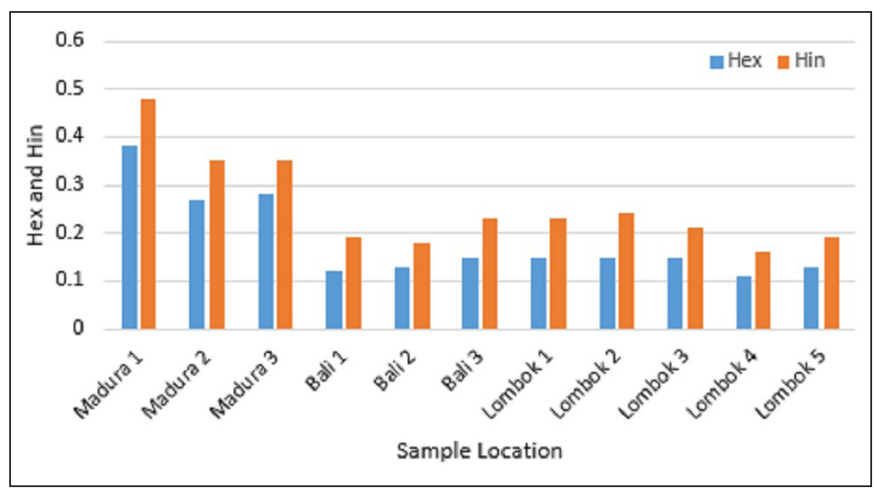

Figure 2. External and Internal Hazard Indices on Beach Sand Samples

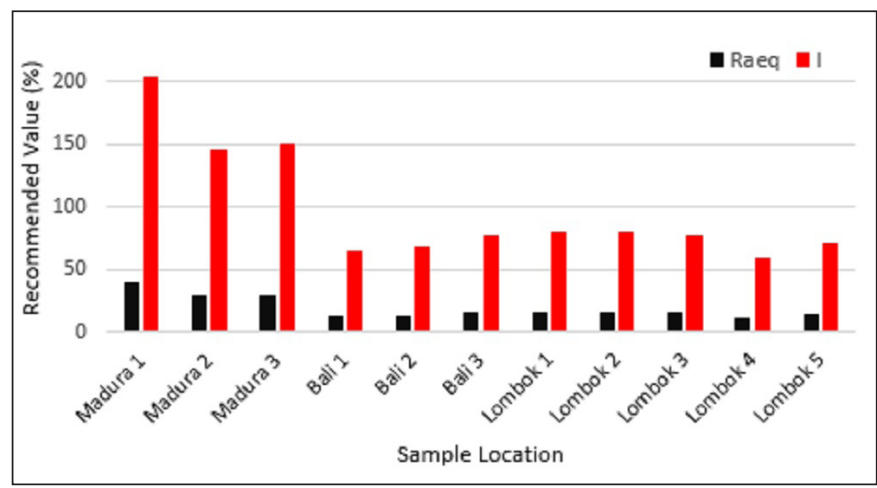

Figure 3. Recommended Value (\%) of Ra Equivalent and Gamma Activity Concentration Index in the Sample

\section{DISCUSSION}

\section{The Concentration of ${ }^{226} \mathrm{Ra},{ }^{232} \mathrm{Th}$ and ${ }^{40} \mathrm{~K}$}

These study findings showed that the characteristic of radionuclides activity from ${ }^{226} \mathrm{Ra}$ was found in Madura, Bali, and Lombok slightly differed from each other. Meanwhile, the characteristics of ${ }^{232} \mathrm{Th}$ found that Madura beach sand was considered to have four times higher concentration compared to Bali and Lombok. These radiological variations can be influenced by geological conditions and drainage patterns in each location. The high concentration of the radionuclides found in the beach sand may be due to the continuous deposition of minerals via sea waves (26).
The activity of ${ }^{40} \mathrm{~K}$ radionuclide has the most extensive activity and contribution, followed by ${ }^{226} \mathrm{Ra}$ and ${ }^{232} \mathrm{Th}$. The abundance of ${ }^{40} \mathrm{~K}$ is due to the richness of continental rocks, and it is found in high concentrations in many light minerals. As possible that ${ }^{40} \mathrm{~K}$ remains the dominant isotope found in soil originating from primary weathering (23). Although ${ }^{40} \mathrm{~K}$ occurs naturally in soil, its concentration may be formed by the disposal of liquid, air, solid wastes, or industrial waste that produces naturally radioactive materials (NORMs) such as oil, gas production, and many conventional mining and milling industries. Besides, the extensive use of phosphate fertilizers in cultivated soils can also be a potential source of natural radionuclides (27).

This study found that the activity of ${ }^{40} \mathrm{~K}$ in Madura was twice as much as Bali and Lombok. It might cause that the sand composition in Madura had more organic minerals. The nature of sand absorbs lower radionuclides compared to other organic matters found in soil (23).

Meanwhile, the activity of ${ }^{226} \mathrm{Ra}$ and ${ }^{232} \mathrm{Th}$ was considered higher in almost all samples. Except for Madura, it was considered lower. The differences were caused by chemical speciation or their abundance in the natural environment. Additionally, the absorption behavior of ${ }^{226} \mathrm{Ra}$ and ${ }^{232} \mathrm{Th}$ in marine environmental compartments, such as coastal sands and sediments, depends on $\mathrm{pH}$. ${ }^{226} \mathrm{Ra}$ is usually more absorbed in organic or clay content, especially at $\mathrm{pH}$ conditions close to neutral to alkaline (28). Thus, the measured activity of ${ }^{226} \mathrm{Ra}$ and ${ }^{232} \mathrm{Th}$ in the beach sand is highly dependent on the organic or clay content in the sand. The higher the organic or clay content in the sand, the higher the ${ }^{226} \mathrm{Ra}$ adsorbed on the beach sand.

Looking at the overall activity data, the activity of ${ }^{226} \mathrm{Ra}$, ${ }^{232} \mathrm{Th}$, and ${ }^{40} \mathrm{~K}$ nuclides in Bali and Lombok had almost similar values. It was reasoned that Bali and Lombok are geographically close, which accounts for their almost identical characteristics. Table 2 represents the comparison of the natural radionuclide data across Indonesia. It was found, in general, that there was no significant difference between the radionuclide activity in this study and other regions in Indonesia.

The type of sand also influences the variation of radionuclide activity found in beach sand. A study in Douala Littoral, Cameroon, stated that different types of sand account for different radionuclides activity to used in building materials (9). Another study conducted in Northwest China discussed the magnitude of the natural radionuclide activity of various aggregates used as building materials. The study mentioned that the different 
aggregates of building materials account would reach varying radiation levels to building occupants (29).

Table 3 represents the comparison of the natural radionuclide activity in the sand in several other countries. Our study result compared to Bangladesh and Thailand showed that the activity of ${ }^{226} \mathrm{Ra}$ in 18.18 - $37.86 \mathrm{~Bq} / \mathrm{kg}$ tended to be smaller considering that Bangladesh had 33.3 to $67.4 \mathrm{~Bq} / \mathrm{kg}$ and Thailand had $1.6-83.1 \mathrm{~Bq} / \mathrm{kg}(10,18)$. Even our result was still under the threshold limit value when compared United Nations Scientific Committee on the Effects of Atomic Radiation (UNSCEAR) standard (30). It was indicated that the ${ }^{226} \mathrm{Ra}$ activity in our study still at a safe level and considered lower than several other countries such as Bangladesh (18).

Moreover, the activity of ${ }^{40} \mathrm{~K}$ in this study still considered lower if compared to other countries such as Thailand (10), Bangladesh (18), and Spain, which had the highest average value (11). Comparing the three natural radionuclides in the study with other countries, the sand beaches in Madura, Bali, and Lombok are still safe. The activities are not much different from the average of other countries.

\section{The Evaluation of Hazardous Radiological Effects}

The average activity values of ${ }^{226} \mathrm{Ra},{ }^{232} \mathrm{Th}$ and ${ }^{40} \mathrm{~K}$ in this study could not provide a direct indication of the radiation hazards associated with the use of beach sand as a building material. Further radiological calculations need to be done using a predetermined formula. After that, compared with safe limits recommended by the international standards.

Table 4 suggests the calculation and analysis of radiological hazards posed by beach sand. Our findings showed that the beach sand in Madura had a higher average $\mathrm{Ra}_{\text {eq }}$ value $(114.54 \mathrm{~Bq} / \mathrm{kg})$ compared to Bali $(48.85 \mathrm{~Bq} / \mathrm{kg})$ and Lombok (50.92 Bq/kg). However, the $\mathrm{Ra}_{\text {eq }}$ values of the three selected locations were still far below the safe limit of $370 \mathrm{~Bq} / \mathrm{kg}(25)$.

$\mathrm{Ra}_{\text {eq }}$ activity was used to compare ${ }^{238} \mathrm{U},{ }^{232} \mathrm{Th}$, and ${ }^{40} \mathrm{~K}$ in beach sand with one quantity. The evaluation of $\mathrm{Ra}_{\mathrm{eq}}$ was based on the assumption that $370 \mathrm{~Bq} / \mathrm{kg}$ of ${ }^{238} \mathrm{U}, 259 \mathrm{~Bq} / \mathrm{kg}$ of ${ }^{232} \mathrm{Th}$, and $4810 \mathrm{~Bq} / \mathrm{kg}$ of ${ }^{40} \mathrm{~K}$ produce the same dose of gamma radiation. The $\mathrm{Ra}_{\text {eq }}$ value can be helpful for guidance to protect the population from radiation exposure (31).

The evaluation of radionuclides' activity also includes the analysis of gamma activity concentration index (I). The gamma index serves as a screening tool for building aggregates that may affect occupant health and potentially cause stochastic effects (32). For building materials to be considered radiologically safe, the value of I value should correspond to the annual effective dose threshold $(\leq 1 \mathrm{mSv}$ ), while the value of ly $\leq 0.5$ corresponds to the annual effective dose $(\leq 0.3 \mathrm{mSv})$ (31). The average gamma activity concentration index for beach sand in Bali and Lombok is 0.35 and 0.37, respectively. This value can meet the limit value of less than 0.5 (33). Meanwhile, the value of I in Madura was 0.83 , which exceeds the safe limit $(>0.5)$. Even at the sampling point with the code, Madura 1 had a value of $1.02(I>1)$.

It was understood that the beach sands in several other countries such as the Guangxi Province, China, and white sand in Langkawi, Malaysia had a slightly smaller average I value of 0.17 and $0.19(22,34)$. However, there was also a report that the beach sand in other areas such as Southern India had a higher value of I (2.35) than this study (35). Even black sand on the island of Langkawi, Malaysia, had a 17-time higher I value (17) than in this study (22). There should be no deterministic effect of radiations since this condition will only occur if the occupant is exposed to doses exceeding $1 \mathrm{~Sv}$. However, the risk of stochastic effect will increase along with the increase of ly value. Therefore, the use of beach sand as a building material should be avoided ( $\mathrm{I}>$ 1 ) to reduce the possibility of stochastic effect $(12,18)$.

External and internal radiations to ${ }^{238} \mathrm{U},{ }^{232} \mathrm{Th}$, and ${ }^{40} \mathrm{~K}$ present in the sand are referred to as the external hazard index (Hex) and the internal hazard index (Hin). The external hazard index refers explicitly to the evaluation of the natural gamma radiation hazard. This index is used to assess the radiological suitability of material. The main purpose of this index is to limit the radiation dose to an acceptable dose limit of $1 \mathrm{mSv} / \mathrm{y}$ (26). While the external exposure results from direct gamma radiation, the internal exposure results from the inhalation of radon gas and short-lived decay products trapped in building enclosures. Radon gas $\left({ }^{222} \mathrm{Rn}\right)$ is a short-lived gas threatening human respiratory organs (31). The gamma radiation hazard is negligible if the Hex and $H$ in values must be less than 0.5.

Based on the analysis of the external (Hex) and Internal (Hin) hazard indexes, the average Hex values in Madura, Bali, and Lombok were 0.31, 0.13, and 0.14, while the average Hin values were $0.39,0.2$, and 0.2 . It can be concluded that the three selected locations are safe (33). According to Table 2, it was found that the Hin values were higher than Hex values. Therefore, special treatment should be prepared to prevent this sand enter the occupant's body. The use of $80 \%$ natural ventilation and $20 \%$ artificial ventilation, such as an Air Conditioner, 
can be a solution to reduce the impact of radiation on building occupants (7).

In conclusion, only one out of four radioactive hazard indicators in Madura exceeded the safe limit. Several previous studies suggested if an I-value was > 0.5 , then the use of beach sand as a building material should be avoided even though several other studies considered it safe. Therefore, a more in-depth study is required for the use of beach sand on Madura Island. Meanwhile, the beach sand in Bali and Lombok is considered safe. This is reasonable since all-hazard indicators in Bali and Lombok are still below safe limits.

\section{CONCLUSION}

The activity of the three types of natural radionuclides was still below the recommended value. The potential radiological hazards of beach sand in Bali and Lombok were still below the safe limit. Meanwhile, it was found that the gamma index value (I) in Madura exceeded the safe limit. Although the other three hazard indicators in Madura are considered safe, a more indepth study is required for the use of beach sand on Madura Island.

\section{ACKNOWLEDGEMENTS}

This study was funded by DIPA PTKMR 2016. Yogi Priasetyono and Murdahayu Makmur as the main contributors of this study.

\section{REFERENCES}

1. Chandrasekaran S, Sankaran PG, Venkatraman B. Assessment of Heavy Metals and Radionuclides $\left({ }^{238} \mathrm{U},{ }^{232} \mathrm{Th}\right.$ and $\left.{ }^{40} \mathrm{~K}\right)$ Concentration of Beach Sands Collected from East Coast of Tamilnadu, India With Multivariate Statistical Approach. International Journal of Environmental Analytical Chemistry. 2020;1(1):1-23. https://doi.org/10.1080/03067319. 2020.1779240

2. Siswanto R, Suyoso H, Hayu GA. Pengaruh Penggunaan Pasir Pantai Sebagai Agregat Halus dan Cangkang Kerang sebagai Subtitusi Parsial Semen terhadap Kuat Tekan Beton. Jurnal Rekayasa Sipil dan Lingkungan. 2017;1(2):192199. http://doi.org/10.19184/jrsl.v1i02.6895

3. Hadi S. Variasi Mortar Pasir Pantai dan Tanah Lempung Dengan Mortar Pasir Sungai Terhadap Kuat Tekan. Media Bina IImiah. 2018;12(7):109116. http://ejurnal.binawakya.or.id/index.php/MBI/ article/view/27

4. Grupen C. Introduction to Radiation Protection. Springer: Siegen; 2010. https://link.springer.com/ book/10.1007/978-3-642-02586-0
5. Shuaibu HK, Khandaker MU, Alrefae T, Bradley DA. Assessment of Natural Radioactivity and Gammaray Dose in Monazite Rich Black Sand Beach of Penang Island, Malaysia. Marine Pollution Bulletin. 2017;119(1):423-428. http://doi.org/10.1016/j. marpolbul.2017.03.026

6. Amana MS. Radiation Hazard Index of Common Imported Ceramic Using for Building Materials in Iraq. Australian Journal of Basic and Applied Sciences. 2017;11(10):94-102. http://www. ajbasweb.com/old/ajbas/2017/July/94-102.pdf

7. Joel ES, De DK, Omeje M, Adewoyin O, Olawole OC, Akinwumi A, et al. Assessment of Background Radionuclides and Gamma Dose Rate Distribution in Urban-Setting and Its Radiological Significance. Scientific African. 2020;8(e00377):1-8. http://doi. org/10.1016/j.sciaf.2020.e00377

8. Ghias S, Satti KH, Khan M, Dilband M, Naseem A, Jabbar A, et al. Health Risk Assessment of Radioactive Footprints of The Urban Soils in The Residents of Dera Ghazi Khan, Pakistan. Chemosphere. 2021;267(129171):1-10. https://doi. org/10.1016/j.chemosphere.2020.129171

9. Guembou Shouop CJ, Ndontchueng Moyo M, Chene G, Nguelem Mekontso EJ, Motapon $\mathrm{O}$, Kayo SA, et al. Assessment of Natural Radioactivity and Associated Radiation Hazards in Sand Building Material Used in Douala Littoral Region of Cameroon, Using Gamma Spectrometry. Environmental Earth Sciences. 2017;76(164):1-12. https://doi.org/10.1007/s12665-017-6474-3

10. Malain D, Regan PHH, Bradley DAA, Matthews M, Al-sulaiti HAA, Santawamaitre T. An Evaluation of The Natural Radioactivity in Andaman Beach Sand Samples of Thailand After The 2004 Tsunami. Applied Radiation and Isotopes. 2012;70(8):1467-1474. http://doi.org/10.1016/i. apradiso.2012.04.017

11. Arnedo MA, Tejera A, Rubiano JG, Alonso H, Gil $J M$, Rodriguez R, et al. Natural Radioactivity Measurements of Beach Sands in Gran Canaria, Canary Islands (Spain). Radiation Protection Dosimetry. 2013;156(1):75-86. $\quad$ http://doi. org/10.1093/rpd/nct044

12. Punniyakotti J, Ponnusamy V. Radionuclides of ${ }^{238} \mathrm{U},{ }^{232} \mathrm{Th}$ and ${ }^{40} \mathrm{~K}$ in Beach Sand of Southern Regions in Tamilnadu State, India ( Post-Tsunami ). Indian Journal of Pure \& Applied Physics. 2017;55(1):218-230. https://www.researchgate. net/publication/316939211_Radionuclides of 238U 232Th_and 40K in beach sand of southern regions in Tamilnadu State India Post-Tsunami

13. Arriola-Velásquez A, Tejera A, Guerra JG, Alonso I, Alonso $\mathrm{H}$, Arnedo MA, et al. Spatio-Temporal Variability of Natural Radioactivity as Tracer of Beach Sedimentary Dynamics. Estuarine, Coastal and Shelf Science. 2019;231(106476):1-10. https:// doi.org/10.1016/j.ecss.2019.106476 
14. Fares S. Measurements of Natural Radioactivity Level in Black Sand and Sediment Samples of The Temsah Lake Beach in Suez Canal Region in Egypt. Journal of Radiation Research and Applied Sciences. 2017;10(3):194-203. http://doi. org/10.1016/j.jrras.2017.04.007

15. Lyngkhoi B, Nongkynrih P. Radioactivity in Building Materials and Assessment of Risk of Human Exposure in The East Khasi Hills District, Meghalaya, India. Egyptian Journal of Basic and Applied Sciences. 2020;7(1):194-209. https://doi.o $\mathrm{rg} / 10.1080 / 2314808 X .2020 .1781747$

16. Madruga MJ, Miró C, Reis M, Silva L. Radiation Exposure From Natural Radionuclides in Building Materials. Radiation Protection Dosimetry. 2019;185(1):49-57. https://doi.org/10.1093/rpd/ ncy256

17. Maxwell O, Emmanuel JS, Olusegun AO, Cyril E-EO, Ifeanyi AT, Embong Z. A Study of Natural Radioactivity in Some Building Materials in Nigeria. Radiation Protection Dosimetry. 2019;183(3):332335. https://doi.org/10.1093/rpd/ncy121

18. Asaduzzaman K, Mannan F, Khandaker MU, Farook MS, Elkezza A, Amin YBM, et al. Assessment of Natural Radioactivity Levels and Potential Radiological Risks of Common Building Materials Used in Bangladeshi Dwellings. PLOS One. 2015;10(e0140667):1-16. https://doi.org/10.1371/ journal.pone.0140667

19. Agency for Toxic Substances and Disease Registry. Toxicological Profile for Thorium. ATSDR's Toxicological Profiles. United States: U.S. Department of Health and Human Services; 2019. https://www.atsdr.cdc.gov/ToxProfiles/tp147.pdf

20. Priasetyono Y, Makmur M, Yahya MN, Putra DIP, Prihatiningsih WR, Suseno H. Updating of Baseline Radionuclides Concentration in Jakarta Bay. IOP Conference Series: Earth and Environmental Science. 2020;584(012067):1-6. https://doi. org/10.1088/1755-1315/584/1/012067

21. Marwoto J, Muslim M, Aprilia ZD, Purwanto P, Makmur M. Sebaran Aktivitas Radionuklida Alam dalam Sedimen di Perairan Sluke Rembang, Jawa Tengah. Jurnal Kelautan Tropis. 2019;22(2):141146. https://doi.org/10.14710/jkt.v22i2.4881

22. Khandaker MU, Asaduzzaman K, Sulaiman AF Bin, Bradley DA, Isinkaye MO. Elevated Concentrations of Naturally Occurring Radionuclides in Heavy Mineral-Rich Beach Sands of Langkawi Island, Malaysia. Marine Pollution Bulletin. 2018;127(1):654-663. https://doi.org/10.1016/j. marpolbul.2017.12.055

23. Ahmad AY, Al-Ghouti MA, AlSadig I, Abu-Dieyeh M. Vertical Distribution and Radiological Risk Assessment of ${ }^{137} \mathrm{Cs}$ and Natural Radionuclides in Soil Samples. Scientific Reports. 2019;9(1):1-14. http://doi.org/10.1038/s41598-019-48500-x
24. Elnobi S, Harb S, Ahmed NK. Influence of Grain Size on Radionuclide Activity Concentrations and Radiological Hazard of Building Material Samples. Applied Radiation and Isotopes. 2017;130(1):4348. http://doi.org/10.1016/j.apradiso.2017.09.021

25. Nuclear Energy Agency-Organisation for Economic Co-operation and Development. Exposure to Radiation From The Natural Radioactivity in Building Materials. Paris: Nuclear Energy AgencyOrganisation for Economic Co-operation and Development; 1979. https://www.oecd-nea.org/rp/ reports/1979/exposure-to-radiation-1979.pdf

26. Ravisankar R, Chandramohan J, Chandrasekaran A, Jebakumar JP, Vijayalakshmi I, Vijayagopal P, et al. Assessments of Radioactivity Concentration of Natural Radionuclides and Radiological Hazard Indices in Sediment Samples from the East Coast of Tamilnadu, India With Statistical Approach. Marine Pollution Bulletin. 2015;97(1-2):419-430. https:// doi.org/10.1016/j.marpolbul.2015.05.058

27. Ribeiro FCA, Lauria D da C, Silva JIR, Lima ESA, Sobrinho NMB do, Pérez DV. Baseline and Quality Reference Values for Natural Radionuclides in Soils of Rio de Janeiro State, Brazil. Revista Brasileira de Ciência do Solo. 2018;42(1):1-15. https://doi.or $\mathrm{g} / 10.1590 / 18069657 \mathrm{rbcs} 20170146$

28. Urso L, Hormann V, Diener A, Achatz M. Modelling Partition Coefficients of Radium in Soils. Applied Geochemistry. 2019;105(1):78-86. https://doi. org/10.1016/j.apgeochem.2019.04.014

29. Shi C, Chen L, Wang Y, Chai L, Qiu G. Natural Radioactivity Evaluation of Local Soil used as Building Materials in Xinchang Section of Beishan Pre-selected Area, Northwest China. IOP Conference Series: Earth and Environmental Science. 2021;728(012007):1-11. https://doi. org/10.1088/1755-1315/728/1/012007

30. United Nations Scientific Committee on the Effects of Atomic Radiation. Sources and Effects of lonizing Radiation. New York: United Nations Publication; 2000. https://doi.org/10.1088/0952-4746/21/1/609

31. Ugbede FO. Distribution of $40 \mathrm{~K}, 238 \mathrm{U}$ and $232 \mathrm{Th}$ and Associated Radiological Risks in River Sand Sediments Across Enugu East, Nigeria. Environmental Nanotechnology, Monitoring \& Management. 2020;14(100317):1-10. https://doi. org/10.1016/j.enmm.2020.100317

32. Kovler K, Friedmann H, Michalik B, Schroeyers W, Tsapalov A, Antropov S, et al. Basic Aspects of Natural Radioactivity. Cambridge: Naturally Occurring Radioactive Materials in Construction; 2017. p. 13-36. https://doi.org/10.1016/B978-0-08102009-8.00003-7

33. Liu X, Lin W. Natural Radioactivity in the Beach Sand and Soil Along the Coastline of Guangxi Province, China. Marine Pollution Bulletin. 2018;135(1):446-450. https://doi.org/10.1016/j. marpolbul.2018.07.057 
34. Soniya SR, Monica S, Prasad VA, Jojo PJ. Assessment of Radiological Consequence of Radioactivity in Monazite Beach Sand in South West Coastal Region in Southern India. Materials Today Proceedings. 2019;16(2):784-791. https:// doi.org/10.1016/j.matpr.2019.05.159

35. Makmur M, Prihatiningsih WR, Yahya MN. Penilaian Dampak Bahaya Radiologis terhadap Radionuklida Natural di Pesisir Pulau Bengkalis. Jurnal Kesehatan Lingkungan Indonesia. 2019;18(2):113-120. https:// doi.org/10.14710/jkli.18.2.113-120
36. Prihatiningsih WR, Suseno $\mathrm{H}$, Makmur M, Yahya MN, Muslim M, Yahya MN. Effect of Regional Oceanographic Processes to The Distribution of Radionuclides in The Coasts of Kalimantan. IOP Conference Series: Earth and Environmental Science. 2020;429(012014):1-9. https://doi. org/10.1088/1755-1315/429/1/012014

37. Kucukomeroglu B, KaradenizA, Damla N, Yesilkanat CM, Cevik U. Radiological Maps in Beach Sands Along Some Coastal Regions of Turkey. Marine Pollution Bulletin. 2016;112(1-2):255-264. http:// dx.doi.org/10.1016/j.marpolbul.2016.08.007 